\title{
Co-doped p-type ZnO:Al-N Thin Films Grown by RF-Magnetron Sputtering at Room Temperature
}

\author{
Raul Ramos ${ }^{a}$ (D), Marcio Peron Franco de Godoy ${ }^{b}$ (D), Elidiane Cipriano Rangel ${ }^{a}$ (D), \\ Nilson Cristino da Cruz ${ }^{a}$, Steven F. Durrant ${ }^{a}$ (D), José Roberto Ribeiro Bortoleto ${ }^{a *}$ (D) \\ ${ }^{a}$ Universidade Estadual Paulista (UNESP), Instituto de Ciência e Tecnologia de Sorocaba, \\ Sorocaba, SP, Brasil \\ ${ }^{b}$ Universidade Federal de São Carlos (UFSCar), Departamento de Física, São Carlos, SP, Brasil
}

Received: February 3, 2020; Revised: May 26, 2020; Accepted: June 1, 2020

\begin{abstract}
This study reports the structural properties of zinc oxide thin films co-doped with aluminum and nitrogen ( $\mathrm{ZnO}: \mathrm{Al}-\mathrm{N})$ grown by $\mathrm{RF}$ magnetron sputtering from an $\mathrm{AZO}\left(\mathrm{ZnO}\right.$ with $\left.2 \mathrm{wt} \% \mathrm{Al}_{2} \mathrm{O}_{3}\right)$ target under nitrogen $\left(\mathrm{N}_{2}\right)$ atmosphere at room temperature $(\mathrm{RT})$. Nitrogen partial pressures of $0.00,0.10,0.25$ and $1.00 \mathrm{mTorr}$ were used. The film thickness was around $270 \mathrm{~nm}$. Ultraviolet-Vis-NIR transmittance (T) spectra of the films revealed T values of 80 to $85 \%$ in the 400 to $700 \mathrm{~nm}$ wavelength range. XRD results indicated that the films had a hexagonal wurtzite structure and were preferentially oriented in the (002) plane. Analyses by EDS indicated that the $\mathrm{N}$ atoms tend to be incorporated into the $\mathrm{ZnO}$ matrix at the expense of oxygen atoms. The ideal $[\mathrm{N}] /[\mathrm{Al}]$ was obtained at a $\mathrm{N}_{2}$ partial pressure of $0.25 \mathrm{mTorr}$, producing a p-type film. For a $[\mathrm{N}] /[\mathrm{Al}]$ of 1.53 , the film also exhibited p-type conduction with an electrical resistivity of $31.92 \Omega$ $\mathrm{cm}$, mobility of $18.65 \mathrm{~cm}^{2} / \mathrm{V} \mathrm{s}$ and carrier density of $1.22 \times 10^{16} \mathrm{~cm}^{-3}$. The low carrier density is attributed to the energetically favorable formation of inactive nitrogen phases instead of acceptor-receiver-acceptor complexes, even at the ideal $[\mathrm{N}] /[\mathrm{Al}]$.
\end{abstract}

Keywords: zinc oxide, p-type doping, co-doping, ZnO:Al-N, room temperature.

\section{Introduction}

Zinc oxide $(\mathrm{ZnO})$ is biodegradable, non-toxic, and composed of elements abundant in the Earth's crust ( $\mathrm{Zn}-132 \mathrm{ppm}$ in the Earth's crust, $\mathrm{O}-49,4 \%$ ), making it important for large-scale applications. Indeed, $\mathrm{ZnO}$ is widely used industrially as an additive for rubber, paints, cosmetics and medicines, amongst others ${ }^{1}$. In addition, since it is a semiconductor with a wide direct bandgap of $3.3 \mathrm{eV}$ and high binding energy excitons $(60 \mathrm{meV})$, it is a strong candidate in new generations of optoelectronic devices, including semiconductors, light-emitting-diodes (LEDs) and lasers ${ }^{1,2}$.

As confirmed by electrical measurements, $\mathrm{ZnO}$ is an intrinsic n-type semiconductor ${ }^{3}$. Following the success of $\mathrm{GaN}$ as a blue light emitter, however, efforts have been remade to obtain $\mathrm{p}$-type doped $\mathrm{ZnO}$, which would permit the fabrication of LEDs, for example. The following strategies have been used to produce p-type doping of $\mathrm{ZnO}$ : (i) group VA element atoms substitute oxygen atoms; (ii) group IA element atoms substitute $\mathrm{Zn}$ atoms; (iii) co-doping with donors and acceptors ${ }^{4}$.

In the case of group VA elements, nitrogen is most adequate considering the atomic radius and valence energy of the $2 p$ states, which are closer to those of oxygen in comparison with other elements whose difference in radius is greater than $50 \%{ }^{5,6}$. Some theoretical studies ${ }^{7}$, however, suggest that nitrogen is a deep acceptor with a high ionization energy $(1.3 \mathrm{eV})$, producing a reduced concentration of holes.

*e-mail: jose.rr.bortoleto@unesp.br
Moreover, Yan et al. ${ }^{8}$ predicted that the $\mathrm{N}$ atom acts in place of $\mathrm{O}$ as an acceptor, but $\mathrm{N}_{2}$ acts as a donor. Already the theoretical study by Lee et al. ${ }^{9}$. indicated that the mechanism of compensation of $\mathrm{N}$ acceptors is energetically favorable in the $\mathrm{ZnO}$ matrix. This implies that even at low doping levels, the $\mathrm{N}$ acceptors are compensated by oxygen vacancies. Based on this reasoning, we conclude that the effects of self-compensation and the low solubility of acceptors in the $\mathrm{ZnO}$ matrix are the prime factors responsible for the instability observed experimentally in p-type $\mathrm{ZnO}$ films, which convert to n-type upon ageing ${ }^{5,10-12}$.

To obtain a greater level of incorporation of $\mathrm{N}$ into the crystalline structure of $\mathrm{ZnO}$, Yamamoto suggested a co-doping of elements that donate charge, acting as an activator of the acceptor element. More specifically, Yamamoto and Katayama-Yoshida suggested that codoping of $\mathrm{ZnO}: \mathrm{N}$ with $\mathrm{Al}$ or $\mathrm{Ga}$ produces acceptor-energetically favorable donor-acceptor complexes, leading to a reduction in the Madelung energy of delocalized nitrogen atoms and increasing the density of acceptor sites. Thus, the ideal concentration relation between acceptor and donor atoms would be 2:1 to obtain p-type $\mathrm{ZnO}^{13,14}$.

Experimentally, studies have used different nitrogen sources ${ }^{15}$ and codopants such as $\mathrm{Ga}^{16}, \mathrm{~B}^{17}, \mathrm{P}^{18}, \mathrm{Ag}^{19,20}$, $\mathrm{In}^{21}$ and $\mathrm{Al}^{22}$. For the co-doping with $\mathrm{Al}$ using magnetron sputtering, $\mathrm{Cho}^{23}$ deposited $\mathrm{ZnO}: \mathrm{Al}-\mathrm{N}$ films at $300^{\circ} \mathrm{C}$, varying the $\mathrm{N}_{2}$ flow rate. Reductions in the carrier density and electronic mobility were observed when the $\mathrm{N}_{2}$ flow rate 
was increased. As a consequence, the electrical resistivity increased from $1.2 \times 10^{-3} \Omega \mathrm{cm}$ to $0.13 \Omega \mathrm{cm}$ for $30 \%$ of $\mathrm{N}_{2}$ in the $\mathrm{N}_{2}+$ Ar mixture. Chou et $a l^{24}$. used $\mathrm{N}_{2} \mathrm{O}$ as a reactive gas and the deposition temperature was held at $500{ }^{\circ} \mathrm{C}$. In this case, $\mathrm{p}$-type conduction was observed with a carrier density of $2.5 \times 10^{17} \mathrm{~cm}^{-3}$ and electrical resistivity of $2.6 \Omega \mathrm{cm}$ for a $\mathrm{p}_{\mathrm{N} 2 \mathrm{O}} /\left(\mathrm{p}_{\mathrm{N} 2 \mathrm{O}}+\mathrm{p}_{\mathrm{Ar}}\right)$ value of $20 \%$. Raising the partial pressure of $\mathrm{N}_{2} \mathrm{O}$, however, changed the electrical conduction to n-type.

Zeng et $a l^{25}$. employed $\mathrm{Zn}$-Al targets containing different concentrations of $\mathrm{Al}$ (0 at.\%, 0.08 at.\%, 0.4 at.\%, 1 at.\% and 4 at.\%). The $\mathrm{N}_{2} \mathrm{O}$ pressure was fixed at $3 \mathrm{~Pa}$ and the deposition temperature was $500{ }^{\circ} \mathrm{C}$. As a result, films with different types of conduction (p-type and n-type) were obtained, the best result being $28.3 \Omega \mathrm{cm}$ at a carrier concentration of $2.52 \times 10^{17} \mathrm{~cm}^{-3}$.

Hence, depending on the concentrations of $\mathrm{Al}$ and $\mathrm{N}$, p-type or n-type doping may be produced. In none of these studies, however, were the electrical properties of the $\mathrm{ZnO}: \mathrm{Al}-\mathrm{N}$ films correlated with the ratio $[\mathrm{N}] /[\mathrm{Al}]$. Therefore, in this work the correlation between $[\mathrm{N}] /[\mathrm{Al}]$ in $\mathrm{ZnO}$ :Al-N films and their structural and electrical properties were investigated. For this, thin films were synthesized by RF magnetron sputtering using $\mathrm{N}_{2}$ as the reactive gas and a $\mathrm{ZnO}: \mathrm{Al}_{2} \mathrm{O}_{3}(2 \mathrm{wt} . \%)$ target. Specifically, the partial pressure of $\mathrm{N}_{2}$ was varied to obtain films with the ideal ratio of $2: 1$. At this proportion, the formation energy of the co-doping $\mathrm{N}-\mathrm{Al}-\mathrm{N}$ system is smaller than that of $\mathrm{N}$ mono-doping, facilitating the increase in the number of holes ${ }^{26}$. In addition, the Fermi level shifts to positions closer to the top of the valence band, allowing a more stable p-type $\mathrm{ZnO}$ film to be obtained ${ }^{27}$.

\section{Experimental Methods}

Glass substrates were used as substrates for the depositions. Each substrate was cleaned for $480 \mathrm{~s}$ in each of distilled water, acetone and isopropanol in an ultrasonic bath. Film deposition was by RF magnetron Sputtering using a 3 inch diameter ceramic AZO $\left(\mathrm{ZnO}\right.$ with 2 wt. $\%$ of $\left.\mathrm{Al}_{2} \mathrm{O}_{3}\right)$ target in an $\mathrm{Ar}$ and $\mathrm{N}_{2}$ atmosphere. The partial pressure of Ar was held at $1.00 \mathrm{mTorr}$, and the partial pressure of $\mathrm{N}_{2}$ was varied $(0.00,0.10,0.25$, and $1.00 \mathrm{mTorr})$. An applied power of $60 \mathrm{~W}$ was used for $30 \mathrm{~min}$. per deposition. The target-substrate separation was $3 \mathrm{~cm}$ and the substrate holder was neither intentionally heated nor polarized.

Film thicknesses, measured using a DEKTAK 150 profilometer, were $\sim 270 \mathrm{~nm}$. An Energy-Dispersive X-ray Spectrometer (EDS) attached to a JSM-6010LA Scanning Electron Microscope was used to estimate film chemical composition. Film structural properties were investigated with a Panalytical X'Pert Powder Diffractometer at grazing incidence $\left(2^{\circ}\right)$, using the $\mathrm{K}_{\alpha}$ emission of $\mathrm{Cu}(1.5406 \AA)$.

Crystallite size, D, was estimated using the Scherrer equation $^{28,29}\left(D=0.9 \lambda /\left(\beta_{m}^{2}-\beta_{s}^{2}\right)^{1 / 2} \cdot \cos (\theta)\right)$, where $\lambda=0.15406 \mathrm{~nm}$, $\beta_{m}$ and $\beta_{s}$ are the experimental and instrumental FWHM of the peak used, respectively. The interplanar distance, $\mathrm{d}$, was found using the Bragg relation $(n \lambda=2 d \sin (\theta))$. For the calibration of the instrumental FWHM a ceramic $\mathrm{ZnO}$ sample produced by sintering, containing sufficiently large grains, such that the FWHM measured could be attributed to the $\mathrm{X}$-ray beam divergence, was used.

Electrical properties such as resistivity, mobility and carrier density were measured using the Hall Effect with an ECOPIA 3000 equipment employing the Van der Pauw method.

The optical transmittance and reflectance measurements were made using a Perkin Elmer UV-Vis-NIR model Lambda 750 spectrometer over the 190 a $2400 \mathrm{~nm}$ wavelength range. Room temperature photoluminescence measurements (PL) were carried out by exciting the samples with the $325 \mathrm{~nm}$ line of a $\mathrm{He}-\mathrm{Cd}$ laser.

\section{Results and Discussions}

\subsection{Composition and structural properties}

Table 1 shows the elemental composition of the AZO target and of the $\mathrm{ZnO}: \mathrm{Al}$ and $\mathrm{ZnO}: \mathrm{Al}-\mathrm{N}$ films. Comparing the composition of the AZO target with that of the $\mathrm{ZnO}: \mathrm{Al}$ film, there is a reduction in $\mathrm{Zn}$ concentration while the concentration of $\mathrm{Al}$ does not change significantly. This may be attributed to the greater rate of re-sputtering of $\mathrm{Zn}$ atoms compared to that of $\mathrm{Al}$ atoms. This difference is related to the greater binding energy of Al-O compared to that of $\mathrm{Zn}-\mathrm{O}$, as well as the enthalpy of formation of $\mathrm{Al}_{2} \mathrm{O}_{3}(\sim-1676 \mathrm{~kJ} / \mathrm{mol})$ being greater than that of $\mathrm{ZnO}(\sim-348 \mathrm{~kJ} / \mathrm{mol})$. In addition, the $\mathrm{ZnO}: \mathrm{Al}$ film is richer in oxygen than the target material.

The concentration (at.\%) of $\mathrm{Zn}$ and $\mathrm{Al}$ did not change with the addition of $\mathrm{N}_{2}$. On the other hand, [O] fell as [N] increased with the increase in the partial pressure of $\mathrm{N}_{2}$. This may indicate that the incorporation of nitrogen occurs preferentially by the substitution of $\mathrm{O}$ atoms in the $\mathrm{ZnO}$ matrix. Table 1 shows the ratio [N]:[Al], which allows the evaluation of the formation of acceptor-donor-acceptor complexes of the type N-Al- $\mathrm{N}^{14,27}$. The samples produced at partial pressures of nitrogen of 0.10 and 0.25 mTorr present ratios close to the ideal of $2: 1$. The sample deposited at $1.00 \mathrm{mTorr}$ has a value much greater than the theoretical value. These data alone, however, do not reveal the form of the incorporation of $\mathrm{N}$ atoms in $\mathrm{ZnO}$.

Figure 1a presents X-ray diffractograms of the $\mathrm{ZnO}: \mathrm{Al}$ and $\mathrm{ZnO}: \mathrm{Al}-\mathrm{N}$ samples described in Table 1. For comparison, a diffractogram of bulk $\mathrm{ZnO}$ produced by sintering is also shown. All the diffractograms show peaks related to the (002) and (103) planes. This implies the growth of polycrystals with a wurtzite structure with the c-axis preferentially aligned perpendicular to the substrate ${ }^{30}$. At a $\mathrm{N}_{2}$ pressure of $1.00 \mathrm{mTorr}$, however, other diffraction peaks such as (100), (101), (102), (110), (200), (112) and (201) are observed, which are in agreement with crystallographic data (JCPDS 79-208). This indicates that with an excess of $\mathrm{N}_{2}$ there is a structural change in the $\mathrm{ZnO}$ matrix, at least an increase in the random spatial orientation of the polycrystals. Moreover, no other peaks which belong to $\mathrm{AlN}, \mathrm{Zn}_{3} \mathrm{~N}_{2}$ or $\mathrm{Al}_{2} \mathrm{O}_{3}$ were detected even though the $[\mathrm{N}] /[\mathrm{Al}]$ ratio is as high as $4: 1$.

Figure $1 \mathrm{~b}$ and the Table 2 present the diffraction angles and FWHM of the (002) peak. In addition, the lattice parameters $a$ and $c$ deduced from the positions of the (002) and (103) peaks are shown, together with the crystallite sizes estimated using the Scherrer equation. Comparing the 
Table 1: Composition (at.\%) of the AZO target and of the $\mathrm{ZnO}: \mathrm{Al}$ and $\mathrm{ZnO}: \mathrm{Al}-\mathrm{N}$ films deposited at different partial pressures of $\mathrm{N}_{2}$.

\begin{tabular}{|c|c|c|c|c|c|}
\hline $\mathrm{N}_{2}$ Pressure (mTorr) & $\mathrm{Zn}[$ at. $\% \pm 5 \%$ ] & $\mathrm{Al}$ [at. $\% \pm 5 \%$ ] & $\mathrm{O}$ [at.\% $\% 5 \%$ ] & $\mathrm{N}$ [at. $\% \pm 5 \%$ ] & {$[\mathrm{N}] /[\mathrm{Al}]$} \\
\hline 0.00 & 52.90 & 1.97 & 45.07 & 0.00 & 0 \\
\hline 0.10 & 52.50 & 1.92 & 42.63 & 2.94 & 1.53 \\
\hline 0.25 & 52.59 & 1.72 & 42.06 & 3.63 & 2.11 \\
\hline 1.00 & 51.81 & 1.90 & 38.63 & 7.66 & 4.03 \\
\hline AZO target & 55.01 & 1.71 & 43.28 & & \\
\hline
\end{tabular}

Table 2: Diffraction angle and FWHM of the (002) peak. Also shown are the lattice parameters $a$ and $c$ deduced from the positions of the (002) and (103) peaks, as well as the crystallite size, D, estimated for each sample.

\begin{tabular}{cccccc}
\hline$[\mathrm{N}] /[\mathrm{Al}]$ ratio & $2 \theta(002)\left({ }^{\circ}\right)$ & FWHM $\left(^{\circ}\right)$ & $a(\mathrm{~nm})$ & $c(\mathrm{~nm})$ & $D(\mathrm{~nm})$ \\
\hline 0.00 & 33.86 & 0.61 & 0.32594 & 0.52903 & 16.180 \\
\hline 1.53 & 34.05 & 0.58 & 0.32544 & 0.52617 & 17.496 \\
\hline 2.11 & 34.02 & 0.57 & 0.32607 & 0.52662 & 17.767 \\
\hline 4.03 & 33.91 & 0.53 & 0.33256 & 0.52828 & 19.755 \\
\hline ZnO bulk & 34.42 & 0.33 & 0.32506 & 0.52068 & 25.515 \\
\hline
\end{tabular}

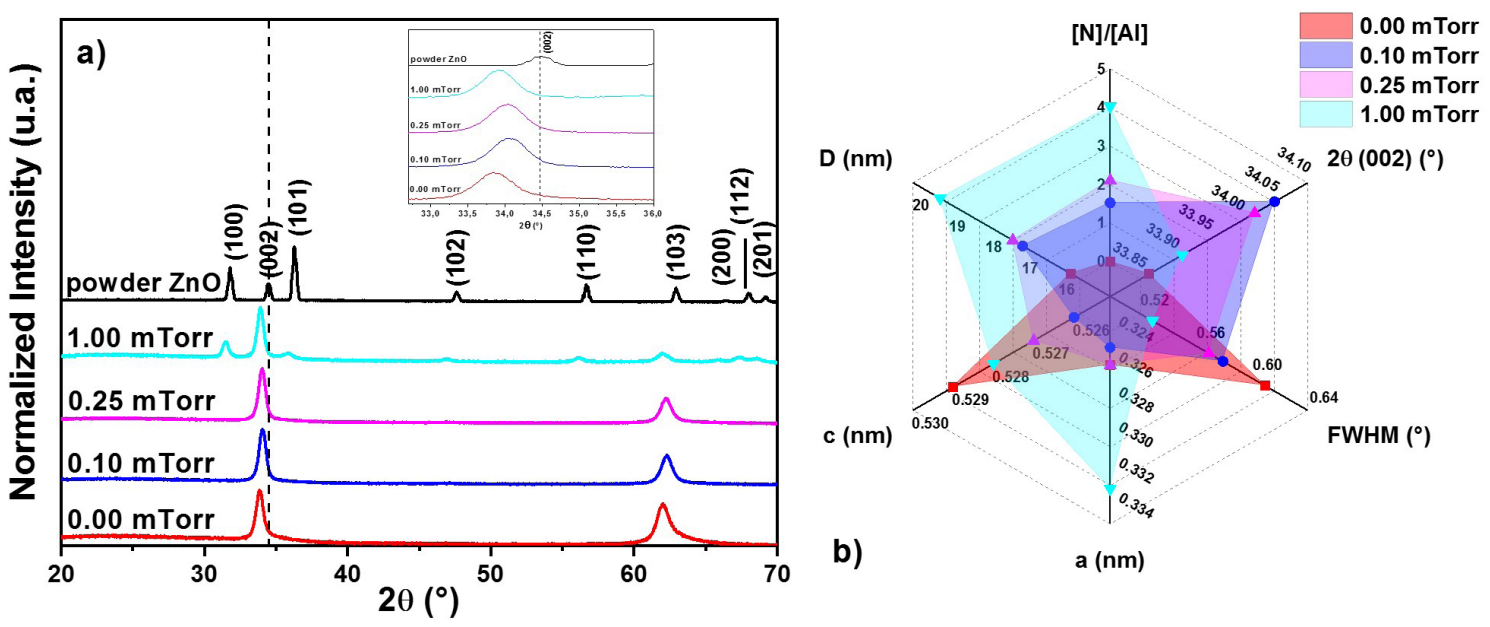

Figure 1: (a) Diffractogram of bulk $\mathrm{ZnO}$ used as a calibration standard for the equipment, and the films sintered with $0.00,0.10,0.25$ and $1.00 \mathrm{mTorr}$ of $\mathrm{N}_{2}$ during the deposition. The inset shows a shift in the (002) peak. Peaks are indexed according to the crystallographic data (JCPDS 79-208). (b) Depiction of values extracted from the X-ray diffractogram.

position of the peaks of the (002) and (103) planes of the $\mathrm{ZnO}$ films with those of bulk $\mathrm{ZnO}$, a shift to lesser angles is observed. When only $\mathrm{Al}$ is added to the lattice, the peak shifts from $34.42^{\circ}$ to $33.86^{\circ}$, implying an expansive stress in the lattice.

With the incorporation of nitrogen into the matrix, the peak shows a tendency to shift to greater angles. This causes a compensation effect in the distortion of the crystalline lattice when $\mathrm{N}$ :Al proportions are close to $2: 1$, since other defects like $\mathrm{Al}$ and $\mathrm{N}$ interstitials tend to increase the lattice parameters. This behavior is supported by the almost constant value of the lattice parameter $a$, except for the sample obtained at $1.00 \mathrm{mTorr}$, while the lattice parameter $c$ increases from $\mathrm{ZnO}$ powder to the $\mathrm{ZnO}: \mathrm{Al}$ film, decreasing again upon co-doping with $\mathrm{N}$. On the other hand, the films present slightly greater crystallite sizes when the partial pressure of $\mathrm{N}_{2}$ increases.

\subsection{Electrical measurements}

Table 3 shows the electrical resistivity, mobility, carrier density and conduction type for the $\mathrm{ZnO}: \mathrm{Al}$ and $\mathrm{ZnO}: \mathrm{Al}-\mathrm{N}$ films. According to the Hall Effect, the $\mathrm{ZnO}: \mathrm{Al}$ film presented an n-type electrical conductivity, as expected ${ }^{31-33}$. The films grown in a $\mathrm{N}_{2}$ atmosphere, with a [N]/[Al] close to 2 , showed a p-type behavior. There was, however, an increase by up to four orders of magnitude in the electrical resistance compared to the $\mathrm{ZnO}$ :Al film, owing mainly to the reduction in carrier density. Finally, the ZnO:Al-N film, grown in excess $\mathrm{N}_{2}$ (partial pressure of 1.00 mTorr) demonstrated n-type behavior and a carrier density of $5.34 \times 10^{15} \mathrm{~cm}^{-3}$. Figure 2 depicts the values of Table 3 , illustrating the behavior of the electrical properties as a function of the $[\mathrm{N}] /[\mathrm{Al}]$ ratio.

Based on the molecular weight of $\mathrm{ZnO}(81.408 \mathrm{~g} / \mathrm{mol})$ and a density of $5.606 \mathrm{~g} / \mathrm{cm}^{3}$, a mole of $\mathrm{ZnO}$ has a $\mathrm{Zn}$ and $\mathrm{O}$ density of $4.148 \times 10^{22} \mathrm{~cm}^{-3}$. From the ratios $([\mathrm{Al}] /([\mathrm{Al}]+[\mathrm{Zn}]))$ and $([N] /([N]+[O]))$ obtained from 
Table 3: Electrical resistivity, mobility, carrier density and type of conduction obtained by Hall Effect measurements.

\begin{tabular}{ccccc}
\hline$[\mathrm{N}] /[\mathrm{Al}]$ & $\begin{array}{c}\rho(\Omega \mathrm{cm}) \\
\pm 10 \%\end{array}$ & $\begin{array}{c}\mu\left(\mathrm{cm}^{2} / \mathrm{Vs}\right) \\
\pm 10 \%\end{array}$ & $\begin{array}{c}n\left(\mathrm{~cm}^{-3}\right) \\
\pm 10 \%\end{array}$ & Type \\
\hline 0.00 & 0.00943 & 6.81 & $9.72 \times 10^{19}$ & $\mathrm{n}$ \\
\hline 1.53 & 31.92 & 18.65 & $1.22 \times 10^{16}$ & $\mathrm{p}$ \\
\hline 2.11 & 116.13 & 9.27 & $6.91 \times 10^{15}$ & $\mathrm{p}$ \\
\hline 4.03 & 148.33 & 11.20 & $5.34 \times 10^{15}$ & $\mathrm{n}$ \\
\hline
\end{tabular}

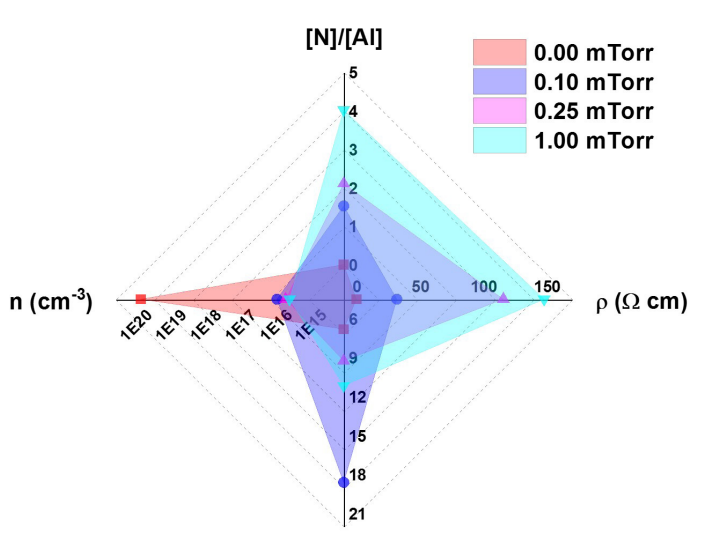

$\mu\left(\mathrm{cm}^{2} / \mathrm{V} . \mathbf{s}\right)$

Figure 2: The carrier density, mobility and electrical resistivity extracted from Hall-probe measurements are depicted with [N]/[Al]. Note that the resistivity increases with increasing [N]/[Al]. The absolute values of the carrier density values are presented.

the EDS data, the hole and maximum electron density, $n_{h}$ and $n_{e}$ may be calculated. For the $\mathrm{ZnO}: \mathrm{Al}$ film, $([\mathrm{Al}] /([\mathrm{Al}]+[\mathrm{Zn}]))$ is $3.59 \%$. Consequently, the expected electron density is $1.49 \times 10^{21} \mathrm{~cm}^{-3}$. The carrier density, however, measured by the Hall Effect is $9.72 \times 10^{19} \mathrm{~cm}^{-3}$. These data imply that the ionization efficiency $\left(n_{\text {Hall }} / n_{e}\right)$ is only $6.53 \%$ (i.e. $6.53 \%$ of the $\mathrm{Al}$ atoms effectively act as donors of charge in n-type $\mathrm{ZnO}: \mathrm{Al})$. A priori, this result may be caused by the compensation mechanism or by the inactivation of $\mathrm{Al}$ caused by the formation of inert complexes, such as the homologous phase $\mathrm{ZnO} / \mathrm{Al}_{2} \mathrm{O}_{3}{ }^{34}$. Such formations are strongly dependent on the quantity of $\mathrm{O}$ available during deposition.

For the $\mathrm{ZnO}: \mathrm{Al}-\mathrm{N}$ film with $[\mathrm{N}] /[\mathrm{Al}]=1.53$, considering the N-Al-N complex as an electron receptor, the hole density would be about $1.46 \times 10^{21} \mathrm{~cm}^{-3}$. Supposing a compensation mechanism between substitutional $\mathrm{N}_{\mathrm{O}}$ and $\mathrm{Al}_{\mathrm{Zn}}$, the hole density would be $1.21 \times 10^{21} \mathrm{~cm}^{-3}$. However, comparing the effective density with the density measured using the Hall Effect, reveals a difference of 5 orders of magnitude $\left(1.22 \times 10^{16} \mathrm{~cm}^{-3}\right)$ lower than expected. This difference is explicable if not all the $\mathrm{Al}$ and $\mathrm{N}$ in the $\mathrm{ZnO}$ matrix act as donors or acceptors, respectively, as proposed by Yamamoto ${ }^{13}$. Instead of forming acceptor-donor-acceptor complexes, the $\mathrm{N}_{\mathrm{O}}$ and $\mathrm{Al}_{\mathrm{Zn}}$ substitutional atoms bind between themselves as $\mathrm{N}_{\mathrm{O}}-\mathrm{Al}_{\mathrm{Zn}}{ }^{35}$. Another possible mechanism is the formation of secondary structures (such as $\mathrm{Zn}_{2} \mathrm{~N}_{3}$ ) , which do not act as acceptors. No such structures, however, were apparent in the X-ray diffractograms.

\subsection{Optical measurements}

Figure 3 a shows the optical transmittance and reflectance spectra of the samples studied here. Interference fringes and optical transparencies of around $80 \%$ in visible range are observed. For wavelengths above $1500 \mathrm{~nm}$, in the spectrum of the $\mathrm{ZnO}: \mathrm{Al}$ film there is an absorption associated with plasmon oscillations ${ }^{37}$, characteristic of materials with a high carrier density. The value measured for this film was $9.72 \times 10^{19} \mathrm{~cm}^{-3}$. This absorption is not observed in the spectra of the films co-doped with $\mathrm{N}$, confirming the low carrier densities (of about $10^{16} \mathrm{~cm}^{-3}$ ) observed in the Hall Effect measurements.

Figure $3 \mathrm{~b}$ shows the absorption spectra of the $\mathrm{ZnO}: \mathrm{Al}$ and $\mathrm{ZnO}: \mathrm{Al}-\mathrm{N}$ films calculated from the transmittance and reflection measurements. The optical absorption edge of the $\mathrm{ZnO}: \mathrm{Al}$ film is at about $3.4 \mathrm{eV}$. This value is slightly above the observed value $(3.3 \mathrm{eV})$ for undoped $\mathrm{ZnO}$ films and is due to filling of the bottom of the conduction band by charge carriers, known as the Burstein-Moss effect ${ }^{38}$. The presence of a step between 2.6 and $3 \mathrm{eV}$ for the $\mathrm{ZnO}$ :Al-N samples indicates the creation of localized states within the bandgap for the samples containing N. Localized states are normally related in $\mathrm{ZnO}$ films to the presence of defects that present deep excitation levels, such as those of oxygen vacancies. In our case, the localized states may be related to the formation of $\mathrm{N}_{\mathrm{O}}-\mathrm{Al}_{\mathrm{Zn}}$ complexes, which also reduce the carrier density as discussed previously. In Figure 3b, the step increases with the concentration of $\mathrm{N}$ incorporated into the $\mathrm{ZnO}: \mathrm{Al}-\mathrm{N}$ films.

Figure 4 shows a photoluminescence (PL) spectra in the 1.5 to $3.7 \mathrm{eV}$ range of $\mathrm{ZnO}: \mathrm{Al}$ and $\mathrm{ZnO}: \mathrm{Al}-\mathrm{N}$ (1.00 mTorr) films. A spectrum of bulk $\mathrm{ZnO}$, also included, exhibits a peak centered at $3.31 \mathrm{eV}$, related to transitions between the bottom of the conduction band and the top of the valence band (NBE). The spectra of the $\mathrm{ZnO}: \mathrm{Al}$ and $\mathrm{ZnO}: \mathrm{Al}-\mathrm{N}$ films show a peak at $3.06 \mathrm{eV}$ and another, wider peak superimposed in 2 to $3 \mathrm{eV}$ range. The first is related to the NBE transition and its shift to lower energies is caused by the influence of the energy levels by the atomic orbitals of the impurities $\mathrm{Al}_{\mathrm{Zn}}$ or $\mathrm{N}_{\mathrm{O}}$ in the $\mathrm{ZnO}$ matrix. The band between 2 and $3 \mathrm{eV}$ derives from localized levels between the conduction and valence bands, which are $\mathrm{V}_{\mathrm{O}}$ or $\mathrm{N}_{\mathrm{O}}-\mathrm{Al}_{\mathrm{Zn}}$ complexes in $\mathrm{ZnO}: \mathrm{Al}$ and $\mathrm{ZnO}: \mathrm{Al}-\mathrm{N}$ films, respectively. For the $\mathrm{ZnO}: \mathrm{Al}-\mathrm{N}$ film there is an extra peak centered at $1.75 \mathrm{eV}$. This transition may indicate the presence of a secondary phase such as $\mathrm{Zn}_{2} \mathrm{~N}_{3}$, which is not detected by the X-rays analyses. However, the formation of this phase could explain the reduction in the alignment of $\mathrm{ZnO}$ polycrystals in the [002] direction. 

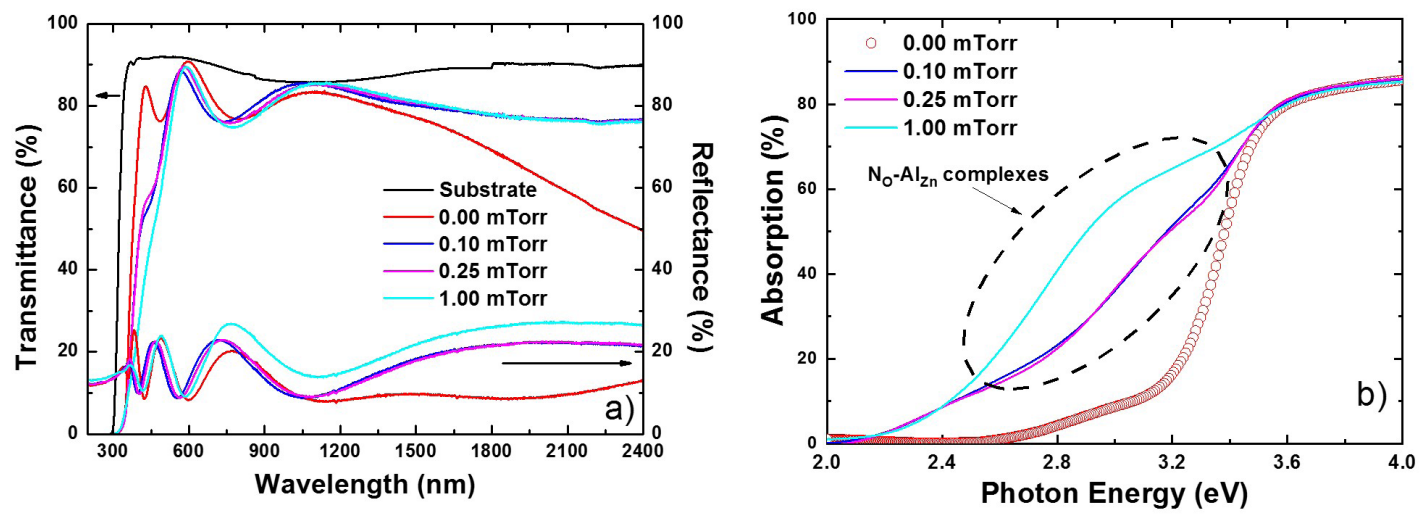

Figure 3: (a) Optical transmittance and reflectance spectra of Al-doped $\mathrm{ZnO}$ films and $\mathrm{Al}$ and $\mathrm{N}$ codoped $\mathrm{ZnO}$ films. For comparison the transmittance spectra of the glass substrate is also shown. (b) Absorption of the following films: $\mathrm{ZnO}: \mathrm{Al}$ and ZnO:Al-N 0.10, 0.25 and $1.00 \mathrm{mTorr}$.

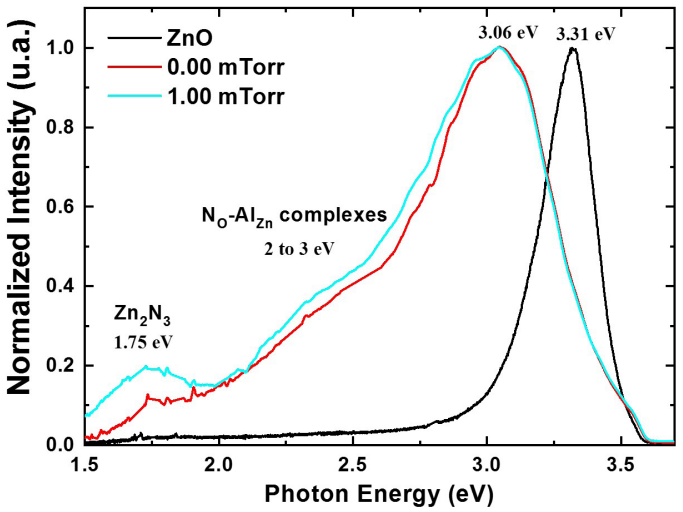

Figure 4: Room temperature photoluminescence spectra of the $\mathrm{ZnO}$, doped $\mathrm{ZnO}: \mathrm{Al}$ and co-doped $\mathrm{ZnO}: \mathrm{Al}-\mathrm{N}$ (1mTorr).

\section{Conclusions}

Films of ZnO:Al-N were obtained using RF magnetron sputtering at different $\mathrm{N}_{2}$ partial pressures. All of the films exhibited a Wurtzite structure with a preferential orientation along the (002) plane. For a $\mathrm{N}_{2}$ partial pressure of 1.00 mTorr the film presented a more random orientation of the crystals. From EDS measurements, it was concluded that the $\mathrm{N}$ atoms tend to be incorporated into the $\mathrm{ZnO}$ matrix by the suppression of oxygen atoms even at low $\mathrm{N}_{2}$ pressures. The ideal value of $[\mathrm{N}] /[\mathrm{Al}]$ was obtained at a $\mathrm{N}_{2}$ partial pressure of $0.25 \mathrm{mTorr}$, producing a film with p-type conduction. For the partial pressure of $0.10 \mathrm{mTorr}$ (equivalent to a $[\mathrm{N}] /[\mathrm{Al}]$ of 1.53 ), the film also exhibited p-type conduction with an electrical resistivity of $31.92 \Omega \mathrm{cm}$, a mobility of $18.65 \mathrm{~cm}^{2} / \mathrm{V} \mathrm{s}$ and a carrier density of $1.22 \times 10^{16} \mathrm{~cm}^{-3}$. PL measurements indicate the formation of defects such as $\mathrm{N}_{\mathrm{O}}-\mathrm{Al}_{\mathrm{Zn}}$ complexes and $\mathrm{Zn}_{2} \mathrm{~N}_{3}$, since the the formation of nitrogen phases is energetically more favorable than the formation of acceptor-donor-acceptor complexes, even at the ideal $[\mathrm{N}] /[\mathrm{Al}]$.

\section{Acknowledgments}

The authors thank the Brazilian agencies CNPq (Proc. 555774/2010-4 and 301622/2012-4) and FAPESP (2017/15853-0) for financial support. This study was also financed in part by CAPES (1795290/2018).

\section{References}

1. Kolodziejczak-Radzimska A, Jesionowski T. Zinc oxidefrom synthesis to application: A review. Materials (Basel). 2014;7(4):2833-81.

2. Dutta S, Chattopadhyay S, Sarkar A, Chakrabarti M, Sanyal D, Jana D. Role of defects in tailoring structural, electrical and optical properties of ZnO. Prog Mater Sci. 2009;54(1):89-136.

3. Ginley DS. Handbook of transparent conductors. New York: Springer; $2010.533 \mathrm{p}$.

4. Reynolds JG, Reynolds CL, Mohanta A, Muth JF, Rowe JE, Everitt HO, et al. Shallow acceptor complexes in p-type $\mathrm{ZnO}$. Appl Phys Lett. 2013;102(15):152114

5. Avrutin BV, Silversmith DJ, Morkoc H. Doping asymmetry problem in $\mathrm{ZnO}$ : current status and outlook. Proc IEEE. 2010;98(7):1269-80.

6. Fan JC, Sreekanth KM, Xie Z, Chang SL, Rao KV. p-Type $\mathrm{ZnO}$ materials: Theory, growth, properties and devices. Prog Mater Sci. 2013;58(6):874-985.

7. Yamamoto T, Katayama-yoshida H. Control of valence states in ZnO by codoping method. Jpn J Appl Phys. 1999;38:L116.

8. Yan Y, Zhang SB, Pantelides ST. Control of doping by impurity chemical potentials: Predictions for p-type ZnO. Phys Rev Lett. 2001;86(25):5723-6.

9. Lee E-C, Kim Y-S, Jin Y-G, Chang KJ. Compensation mechanism for $\mathrm{N}$ acceptors in $\mathrm{ZnO}$. Phys Rev B Condens Matter Mater Phys. 2001;64(8):085120.

10. Gedamu D, Paulowicz I, Kaps S, Lupan O, Wille S, Haidarschin $\mathrm{G}$, et al. Rapid fabrication technique for interpenetrated $\mathrm{ZnO}$ nanotetrapod networks for fast UV sensors. Adv Mater. 2014;26(10):1541-50.

11. Zhang SB, Wei S-H, Zunger A. Intrinsic $n$-type versus $p$-type doping asymmetry and the defect physics of $\mathrm{ZnO}$. Phys Rev B. 2001;63(7):075205.

12. Barnes TM, Olson K, Wolden CA. On the formation and stability of p-type conductivity in nitrogen-doped zinc oxide. Appl Phys Lett. 2005;86(11):1-3.

13. Yamamoto T, Katayama-Yoshida H. Physics and control of valence states in $\mathrm{ZnO}$ by codoping method. Physica B. 2001;302-303:155-62.

14. Yamamoto T. Codoping for the fabrication of $\mathrm{p}$-type $\mathrm{ZnO}$. Thin Solid Films. 2002;420:100-6.

15. Wang Z, Yue Y, Cao Y. Influence of annealing temperature on properties of nitrogen-doped zinc oxide films deposited by magnetron sputtering. Superlattices Microstruct. 2014;65:7-13.

16. Wang J, Elamurugu E, Barradas NP, Alves E, Rego A, Gonçalves $\mathrm{G}$, et al. Co-doping of aluminium and gallium with nitrogen in $\mathrm{ZnO}$ films deposited by RF magnetron sputtering. J PhysCondens Matter. 2008;20(7):075220. 
17. Sui YR, Yao B, Hua Z, Xing GZ, Huang XM, Yang T, et al. Fabrication and properties of B-N codoped p-type $\mathrm{ZnO}$ thin films. J Phys D Appl Phys. 2009;42(6):065101.

18. Sui YR, Yao B, Xiao L, Yang LL, Cao J, Li XF, et al. Fabrication and characterization of $\mathrm{P}-\mathrm{N}$ dual acceptor doped $\mathrm{p}$-type $\mathrm{ZnO}$ thin films. Appl Surf Sci. 2013;287:484-9.

19. Ortega JJ, Ortiz-Hernández AA, Berumen-Torres J, EscobarGalindo R, Méndez-García VH, Araiza JJ. Ag-N dual acceptor doped p-type $\mathrm{ZnO}$ thin films by $\mathrm{DC}$ reactive magnetron cosputtering. Mater Lett. 2016;181:12-5.

20. Li W, Kong C, Qin G, Ruan H, Fang L. P-Type conductivity and stability of Ag-N codoped $\mathrm{ZnO}$ thin films. J Alloys Compd. 2014;609:173-7.

21. Bian J, Li X, Chen L, Yao Q. Properties of undoped n-type $\mathrm{ZnO}$ film and $\mathrm{N}-\mathrm{In}$ codoped p-type $\mathrm{ZnO}$ film deposited by ultrasonic spray pyrolysis. Chem Phys Lett. 2004;393:256-9.

22. Pathak TK, Kumar V, Purohit LP. Sputtered Al-N codoped p-type transparent $\mathrm{ZnO}$ thin films suitable for optoelectronic devices. Optik (Stuttg). 2016;127:603-7.

23. Cho S. Properties of nitrogen and aluminium-codoped $\mathrm{ZnO}$ thin films grown with different nitrogen flow ratios for solar cell applications. Curr Appl Phys. 2010;10(Suppl. 3):S443-6.

24. Chou SM, Hon MH, Leu IC. Synthesis of p-type Al-N codoped ZnO films using $\mathrm{N}_{2} \mathrm{O}$ as a reactive gas by $\mathrm{RF}$ magnetron sputtering. Appl Surf Sci. 2008;255:2958-62.

25. Zeng YJ, Ye ZZ, Lu JG, Zhu LP, Li DY, Zhao BH, et al. Effects of Al content on properties of Al-N codoped $\mathrm{ZnO}$ films. Appl Surf Sci. 2005;249(1-4):203-7.

26. Li P, Deng SH, Li YB, Huang J, Liu GH, Zhang L. Aluminum and nitrogen impurities in Wurtzite $\mathrm{ZnO}$ : first-principles studies. Physica B. 2011;406(17):3125-9.

27. Yang $\mathrm{P}$, Zhao $\mathrm{Y}$, Yang $\mathrm{H}$. Investigation on optoelectronic performances of $\mathrm{Al}, \mathrm{N}$ codoped $\mathrm{ZnO}$ : first-principles method. Ceram Int. 2015;41(2):2446-52.
28. Klug HP, Alexander LE. X-Ray diffraction procedures: for polycrystalline and amorphous materials. 2. ed. New York: John Wiley \& Sons; 1974. 992 p.

29. Roro KT, Kassier GH, Dangbegnon JK, Sivaraya S, Westraadt JE, Neethling JH, et al. Temperature-dependent Hall effect studies of $\mathrm{ZnO}$ thin films grown by metalorganic chemical vapour deposition. Semicond Sci Technol. 2008;23:055021.

30. Bu IYY, Hu T-H. P-type $\mathrm{ZnO}$ films deposited by DC reactive magnetron sputtering using codoping process. J Mater Sci Mater Electron. 2016;28:2852-8.

31. Özgür Ü, Alivov YI, Liu C, Teke A, Reshchikov MA, Doğan $\mathrm{S}$, et al. A comprehensive review of $\mathrm{ZnO}$ materials and devices. J Appl Phys. 2005;98(4):1-103.

32. Ginley DS, Bright C. Transparent conducting oxides. MRS Bull. 2011;25(08):15-8

33. Ellmer K, Klein A, Rech B. Transparent conductive Zinc Oxide: basics and applications in thin film solar cells. New York: Springer; 2008. 453 p.

34. Horwat D, Jullien M, Capon F, Pierson JF, Andersson J, Endrino JL. On the deactivation of the dopant and electronic structure in reactively sputtered transparent Al-doped $\mathrm{ZnO}$ thin films. J Phys D Appl Phys. 2010;43:18-22.

35. Yuan GD, Ye ZZ, Huang JY, Zhu ZP, Perkins CL, Zhang SB. $\mathrm{X}$-ray photoelectron spectroscopy study of Al- and N-co-doped p-type ZnO thin films. J Cryst Growth. 2009;311(8):2341-4.

36. Xian F, Ye J, Gu S, Tan HH, Jagadish C. Structural transition, subgap states, and carrier transport in anion-engineered zinc oxynitride nanocrystalline films. Appl Phys Lett. 2016;109:023109.

37. Ellmer K. Past achievements and future challenges in the development of optically transparent electrodes. Nat Photonics. 2012;6:808-16.

38. Saw KG, Aznan NM, Yam FK, Ng SS, Pung SY. New insights on the burstein-moss shift and band gap narrowing in indiumdoped zinc oxide thin films. PLoS One. 2015;10(10):1-17. 